\title{
Prediksi Tingkat Kriminalitas Menggunakan Jaringan Syaraf Tiruan Backpropagation: Algoritma Levenberg Marquardt di Kota Manado Berbasis Sistem Informasi Geografi
}

\author{
${ }^{1}$ Lindsay Mokosuli, ${ }^{2}$ Winsy Weku, ${ }^{3}$ Luther Latumakulita \\ ${ }^{1}$ Program Studi Matematika, FMIPA, UNSRAT, lindsaymokos uli@gmail.com \\ ${ }^{2}$ Program Studi Matematika, FMIPA, UNSRAT, wins yweku@gmail.com \\ ${ }^{3}$ Program Studi Matematika, FMIPA, UNSRAT, lutherlatu@gmail.com
}

\begin{abstract}
The information needs about crime rate in Manado become a starfing point to conduct this research. It has been done to predict the crime rate in the city of Manado using Levenberg Marquardt algorithm with training to determine the value of learning rate and momentum constant based on the value of the smallest Mean Square Error. Then do the mapping with Crime Mapping and perform cluster the predicted results to see the effect of the crime rate among adjacent districts. The data used is the data theft in the city of Manado in 2007 until 2012. The selected target is the data theft in August 2012 until December 2012. Bunaken district obtain predictive results $=[1.9997,0.1667,2.0000,0.1667,0.0000]$, Mapanget district obtain predictive results $=[25.9995,25.9997,25.9801,8.0335,16.0265]$, Tuminting district obtain predictive results $=[2.0000,2.3786,2.0000,3.1020,3.1020]$, Singkil district obtain predictive results $=[6.6716,6.1388$, 5.6570, 5.4000, 3.0035], Wenang district obtain predictive results $=[3.1316,4.0677,3.0000,9.3971,9.8967]$, Tikala district obtain predictive results $=[0,1,0,0,0]$, Wanea district obtain predictive results $=[6.8911$, $6.6811,1.4788,5.8941,6.9207]$, Sario district obtain predictive results $=[1.0000,1.8381,1.0000,6.0314$, 9.0000], Malalayang district obtain the predicted result $=[44.0000,38.1828,43.1787,38.1935,38.1789]$. By visualization of mapping results predicted, on target August 2012 until October 2012, Mapanget and Malalayang districts have the highest crime rates. While the target of November 2012 and December 2012, Malalayang district have the highest crime rates.
\end{abstract}

Keywords: Levenberg Marquardt Algorithm, Geographic Information System, Spatial Data.

\begin{abstract}
Abstrak
Perlunya informasi tentang tingkat kriminalitas di kota Manado, maka telah dilakukan penelitian untuk memprediksi tingkat kriminalitas di kota Manado menggunakan algoritma Levenberg Marquardt dengan melakukan pelatihan untuk menentukan nilai learning rate dan momentum constant berdasarkan nilai Mean Square Error terkecil. Kemudian dilakukan pemetaan dengan Crime Mapping serta melakukan cluster terhadap hasil prediksi untuk melihat pengaruh tingkat kriminalitas antar kecamatan yang saling berdekatan. Data yang digunakan adalah data pencurian di kota Manado tahun 2007 sampai tahun 2012. Target yang dipilih adalah data pencurian bulan Agustus 2012 sampai Desember 2012. Kecamatan Bunaken me mperoleh hasil prediksi $=[1.9997,0.1667,2.0000,0.1667,0.0000]$, Kecamatan Mapanget memperoleh hasil prediksi $=[25.9995,25.9997,25.9801,8.0335,16.0265]$, kecamatan Tuminting memperoleh hasil prediksi $=[2.0000,2.3786,2.0000,3.1020,3.1020]$, kecamatan Singkil me mperoleh hasil prediksi $=[6.6716$, $6.1388,5.6570,5.4000,3.0035]$, kecamatan Wenang me mperoleh hasil prediksi= [3.1316, 4.0677, 3.0000, 9.3971, 9.8967], kecamatan Tikala mempero leh hasil prediksi $=[0,1,0,0,0]$, kecamatan Wanea mempero leh hasil prediksi $=[6.8911,6.6811,1.4788,5.8941,6.9207]$, kecamatan Sario memperoleh hasil prediksi $=[1.0000,1.8381,1.0000,6.0314,9.0000]$, dan kecamatan Malalayang memperoleh hasil prediksi= [44.0000, 38.1828, 43.1787, 38.1935, 38.1789]. Secara visualisasi pemetaan hasil prediksi, pada target Agustus 2012 sampai Oktober 2012, kecamatan Malalayang dan Mapanget memiliki tingkat kriminalitas tertinggi. Sedangkan pada target November 2012, dan Desember 2012, kecamatan Malalayang memiliki tingkat kejahatan tertinggi.
\end{abstract}

Kata kunci: A lgorit ma Levenberg Marquardt, Sistem Informasi Geografi, Data Spasial.

\section{Pendahuluan}

Tindak kriminal merupakan suatu masalah sosial yang tidak dapat dihindari oleh kehidupan bermasyarakat. Dari tahun ke tahun, tingkat kriminalitas terkadang mengalami penurunan dan peningkatan serta mempunyai tingkatan yang berbeda-beda di setiap daerahnya. Hal tersebut pun terjadi di Kota Manado. Oleh karena itu, diperlukan informasi untuk mengetahui 
tingkat kriminalitas di masing-masing kecamatan di kota Manado agar dapat diakses oleh masyarakat atau dengan distribusi informasi ke publik dan dapat mempermudah aparat kepolisian untuk mengambil keputusan untuk mengetahui pola tindak kejahatan di kota Manado.

Penelitian ini bertujuan untuk memetakan tingkat kriminalitas di kota Manado secara spasial dan memprediksi tingkat kriminalitas untuk beberapa bulan kedepan, serta mengelompokkan suatu wilayah berdasarakan tingkat kriminalitasnya sehingga dapat memberikan informasi-informasi yang dibutuhkan tentang kriminalitas di kota Manado terlebih khusus tentang kasus pencurian.

\subsection{Sistem Informasi Geografi (SIG)}

SIG merupakan suatu alat yang dapat digunakan untuk mengelolah (input, manajemen, proses, dan output) data spasial atau data yang bereferensi geografis[6]. SIG sebagai suatu system berbasis computer yang mempunyai kemampuan untuk menangani data geospatial, dalam bentuk: (a) pemasukan, (b) manajemen, (c) pengolahan dan analisis, serta (d) pengembangan produk percetakan[3].

\subsubsection{Pemetaan Kriminalitas}

Pemetaan tindak kejahatan adalah suatu kegiatan pemrosesan dan pengontrolan terhadap data kriminal spasial yang output-nya ditampilkan secara visual sesuai dengan kebutuhan pengguna [1].

Pada dasarnya, pemetaan tindak kejahatan merupakan bagian dari analisis kriminal [4]. Pemetaan ini mempunyai tiga peran dalam analisis kriminal, yaitu:

1. Menyediakan fasilitas analis is visual dan analisis statistika,

2. Sebagai jembatan untuk menghubungkan data penunjang seperti data sensus, data jumlah penduduk dan data lokasi pos polisi,

3. Menampilkan output berupa data visual.

\subsection{Jaringan Syaraf Tiruan (JST)}

JST adalah paradigma pemrosesan suatu informasi yang terinspirasi oleh sistim sel syaraf biologi, sama seperti otak yang memproses suatu informasi. Elemen mendasar dari paradigma tersebut adalah struktur yang baru dari sistim pemrosesan informasi

\subsubsection{Backpropagation}

Salah satu metode JST adalah backpropogation. Metode ini melatih jaringan untuk mendapatkan keseimbangan antara kemampuan jaringan untuk mengenali pola yang digunakan selama pelatihan serta kemampuan jaringan untuk memberikan respon yang benar terhadap pola yang dipakai selama pelatihan [7].

Masalah utama yang terdapat dalam backpropagation ialah lamanya proses iterasi yang dilakukan. Satu epoch adalah satu cycle (putaran) dari pasangan pelatihan yang pertama sampai pasangan pelatihan yang terakhir. Backpropagation tidak dapat memastikan berapa epoch yang harus dilalui sampai pola yang diinginkan terpenuhi. Oleh karena itu terdapat beberapa cara yang digunakan untuk mengoptimalkan proses iterasi [8], yaitu:

1. Pemilihan bobot dan bias awal

2. Laju Pembelajaran (Learning Rate)

3. Momentum

Pada tahap pembelajaran dalam algoritma backpropagation, diperlukan suatu kondisi untuk menghentikan proses pembelajaran dan sebagai pengukuran keakurasian jaringan da lam mengenali pola yang diberikan. Ada beberapa perhitungan error yang digunakan, salah satunya adalah Mean Squared Error (MSE).

Mean Squared Error (MSE) adalah error rata-rata kuadrat dari selisih antara output jaringan dengan output target. Tujuannya adalah memperoleh nilai error sekecil mungkin secara iteratif dengan mengganti nilai bobot yang terhubung pada semua neuron pada jaringan. Rumus perhitungan MSE adalah sebagai berikut: 


$$
M S E=\frac{1}{2} \sum_{i=1}^{N}\left(t_{k}-o_{y k}\right)^{2}
$$

dimana

$t_{k} \quad=$ nilai output target

$o_{y k} \quad=$ nilai output sistem

\subsubsection{Algoritma Le venberg Marquardt}

Algoritma Levenberg-Marquardt merupakan pengembangan algoritma backpropagation standar. Algoritma pelatihan dengan metode Levenberg Marquardt dapat dijabarkan sebagai berikut:

\section{Langkah 0:}

1. Inisialisasi bobot awal dengan bilangan acak kecil

2. Inisialisasi Epoch 0, MSE $\neq 0$

3. Tetapkan maksimum epoch, parameter Levenberg_Marquardt $(\eta>0)$, faktor $\tau$ dan target error.

\section{Langkah 1:}

Jika kondisi penghentian belum terpenuhi (epoch < maksimum epoch atau MSE > target error), lakukan langkah berikutnya.

\section{Langkah 2:}

1. epoch $=$ epoch +1

2. Untuk setiap pasangan data pelatihan, lakukan langkah 3-4.

\section{Langkah 3:}

Unit output $Y$ menerima target pola yang berhubungan dengan pola input pelatihan. Jika diberikan $N$ pasangan input data pelatihan $\left(x_{r}, t_{r}\right), r=1,2, \ldots, N$ dengan $x_{r}$ adalah input dan $t_{r}$ target yang akan dicapai. Kesalahan pada suatu data pelatihan ke- $r$ didefinis ikan sebagai:

$e_{r}=t_{r}-y_{r}$

Dengan:

$e_{r} \quad=$ Kesalahan pada unit output

$t_{r} \quad=$ Keluaran yang diinginkan (acuan/target)

$y_{r} \quad=$ keluaran aktual

$e$ adalah vektor kesalahan berukuran $N \times 1$ yang tersusun dari $e_{r}, r=1,2, \ldots, N$. $e$ dapat dituliskan sebagai:

$e=\left[\begin{array}{llll}e_{1} & e_{2} & \cdots & e_{N}\end{array}\right]^{T}$

Misal bobot dan bias koneksi dinyatakan dalam vektor $\boldsymbol{w}, \boldsymbol{w}$ merupakan vektor berukuran $((2+n) p+1) \times 1$ dapat dituliskan sebagai:

$\boldsymbol{w}=\left[\begin{array}{llll}w_{j} & b 2 & v_{i j} & b 1_{j}\end{array}\right]^{T}$

Kesalahan suatu pelatihan jaringan oleh vektor bobot dan bias koneksi $\boldsymbol{w}$ pada suatu data pelatihan ke- $r$ menjadi:

$$
\begin{aligned}
e_{r}(\boldsymbol{w}) & =\left(t_{r}-y_{r}\right) \\
& =\left(t_{r}-f\left(x_{r}, \boldsymbol{w}\right)\right)
\end{aligned}
$$

Vektor kesalaahan oleh vektor bobot dan bias koneksi $\boldsymbol{w}$ menjadi $\boldsymbol{e}(\boldsymbol{w})$ berukuran $N \times 1$ yang tersusun dari $e_{r}(\boldsymbol{w})$ dengan $r=1,2, \ldots, N$.

Hitung fungsi jumlah kuadrat error dengan persamaan: 


$$
E(w)=\frac{1}{2} e^{T}(w) e(w)
$$

Hitung matriks Jacobian untuk vektor bobot dan bias koneksi:

$$
\boldsymbol{I}(\boldsymbol{w})=\left[\frac{\partial e_{r}}{\partial w}\right]_{N x((2+n) p+1)}
$$

Untuk $r=1,2, \ldots, N$

a. Hitung matriks Hessian untuk vektor bobot dan bias koneksi.

$$
\boldsymbol{H}(\boldsymbol{w})=\left\lfloor\boldsymbol{J}^{T}(w) \boldsymbol{J}(w)+\eta \boldsymbol{I}\right\rfloor_{((2+n) p+1) x((2+n) p+1)}
$$

b. Hitung perubahan vektor bobot dan bias dengan persamaan:

$$
\Delta \boldsymbol{w}=-\left\lfloor[\boldsymbol{H}(w)]^{-1} \boldsymbol{J}^{T}(w) e(w)\right\rfloor_{((2+n) p+1) x 1}
$$

c. Hitung vektor bobot dan bias baru

$$
\boldsymbol{w}(\text { baru })=\boldsymbol{w}(\text { lama })+\Delta w
$$

d. Hitung kesalahan yang terjadi oleh bobot dan bias koneksi yang baru.

$$
E(\boldsymbol{w}(\text { baru }))=\frac{1}{2} e(w(\text { baru }))^{T} e(w(\text { baru }))
$$

e. Bandingkan $E(\boldsymbol{w})$ dengan $E(\boldsymbol{w}($ baru $))$

1. Jika $E(\boldsymbol{w}) \leq E(\boldsymbol{w}($ baru $))$ maka didapatkan $\eta=\eta * \tau$ dan kembali ke langkah a.

2. Jika $E(\boldsymbol{w})>E(\boldsymbol{w}($ baru $))$ maka didapatkan $\eta / \tau$

$$
\boldsymbol{w}(t+1)=\boldsymbol{w}(t)+\boldsymbol{\Delta} \boldsymbol{w} \text { kembali ke langkah } 2 .
$$

\subsection{Indeks Moran}

Nilai yang dihasilkan dalam perhitungan indeks Moran berkisar antara $-1<I<1$. Nilai $I$ dinyatakan dengan [5]:

1. $I_{0}=-\frac{1}{n}-1$ mendekati nol berarti tidak ada autokorelasi spasial

2. $I>I_{0}$ berarti bahwa terdapat autokorelasi spasial positif

3. $I<I_{0}$ berarti bahwa terdapat autokorelasi spasial negatif

Pencaran Moran menyediakan suatu analis is eksplorasi secara visual untuk mendeteksi autokorelasi spasial [2]. Secara visual pencaran Moran terbagi atas 4 kuadran

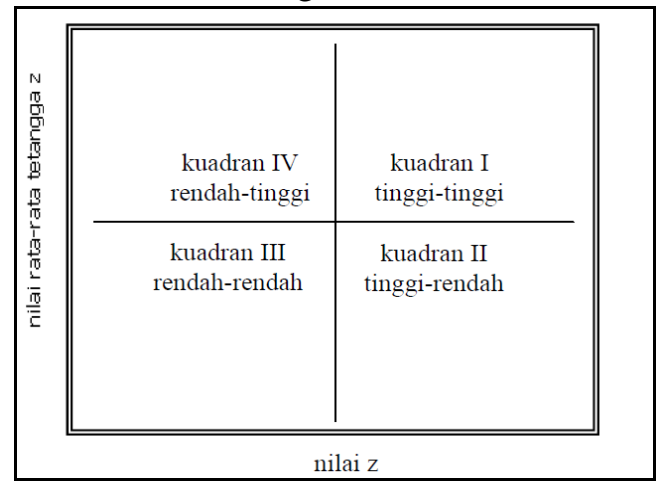

Gambar 1. Kuadran Pencaran Moran

\section{Metode Penelitian}

Penelitian ini menggunakan data sekunder tentang kriminalitas yang berhubungan dengan pencurian di kota Manado dari tahun 2007-2012 secara spasial yaitu data dari sembilan kecamatan di kota Manado, Sulawesi Utara.

Prosedur penelitian ini adalah sebagai berikut:

1. Pengumpulan data 


\section{Pengolahan data}

a. Membuat digitasi peta menggunakan arcview

b. Membuat visualisasi peta

c. Melakukan prediksi dengan algoritma Levenberg Marquardt menggunakan Matlab

d. Melakukan pengelompokan tingkat pencurian antara target dan hasil prediksi

3. Menarik kesimpulan dan member saran untuk penelitian selanjutnya.

\section{Hasil Dan Pembahasan}

Learning Rate (lr) dan Momentum Constant (mc) yang ditentukan ia lah berkisar antara 0.10.9. Dengan melihat nilai Mean Square Error (MSE) terkecil, maka lr dan mc tersebut yang digunakan. Nilai MSE terendah kecamatan Bunaken adalah 0.8414 dengan $\mathrm{lr}=0.6$ dan $\mathrm{mc}=0.4$, nilai MSE terendah kecamatan Mapanget adalah 14.3357 dengan $\mathrm{r}=0.1$ dan $\mathrm{mc}=0.3$, nilai MSE terendah kecamatan Tuminting adalah 1.6081 dengan $\mathrm{lr}=0.2$ dan $\mathrm{mc}=0.1$, nilai MSE terendah kecamatan Singkil adalah 5.3643 dengan $\mathrm{r}=0.1$ dan $\mathrm{mc}=09$, nilai MSE terendah kecamatan Wenang adalah 4.0841 dengan $\mathrm{l}=0.8$ dan $\mathrm{mc}=0.4$, nilai MSE terendah kecamatan Tikala adalah 0.0372 dengan $\mathrm{lr}=0.1$ dan $\mathrm{mc}=0.7$, nilai MSE terendah dari data yang diperoleh di kecamatan Wanea adalah 0.8375 dengan $\mathrm{lr}=0.8$ dan $\mathrm{mc}=0.1$, nilai MSE terendah dari data yang diperoleh di kecamatan Sario adalah 2.8807 dengan $\mathrm{r}=0.4$ dan $\mathrm{mc}=0.1$, dan nilai MSE terendah kecamatan Malalayang adalah 11.6296 dengan $\mathrm{r}=0.2$ dan $\mathrm{mc}=0.7$.

Hasil prediksi yang diperoleh dipetakan pada Gambar 2.

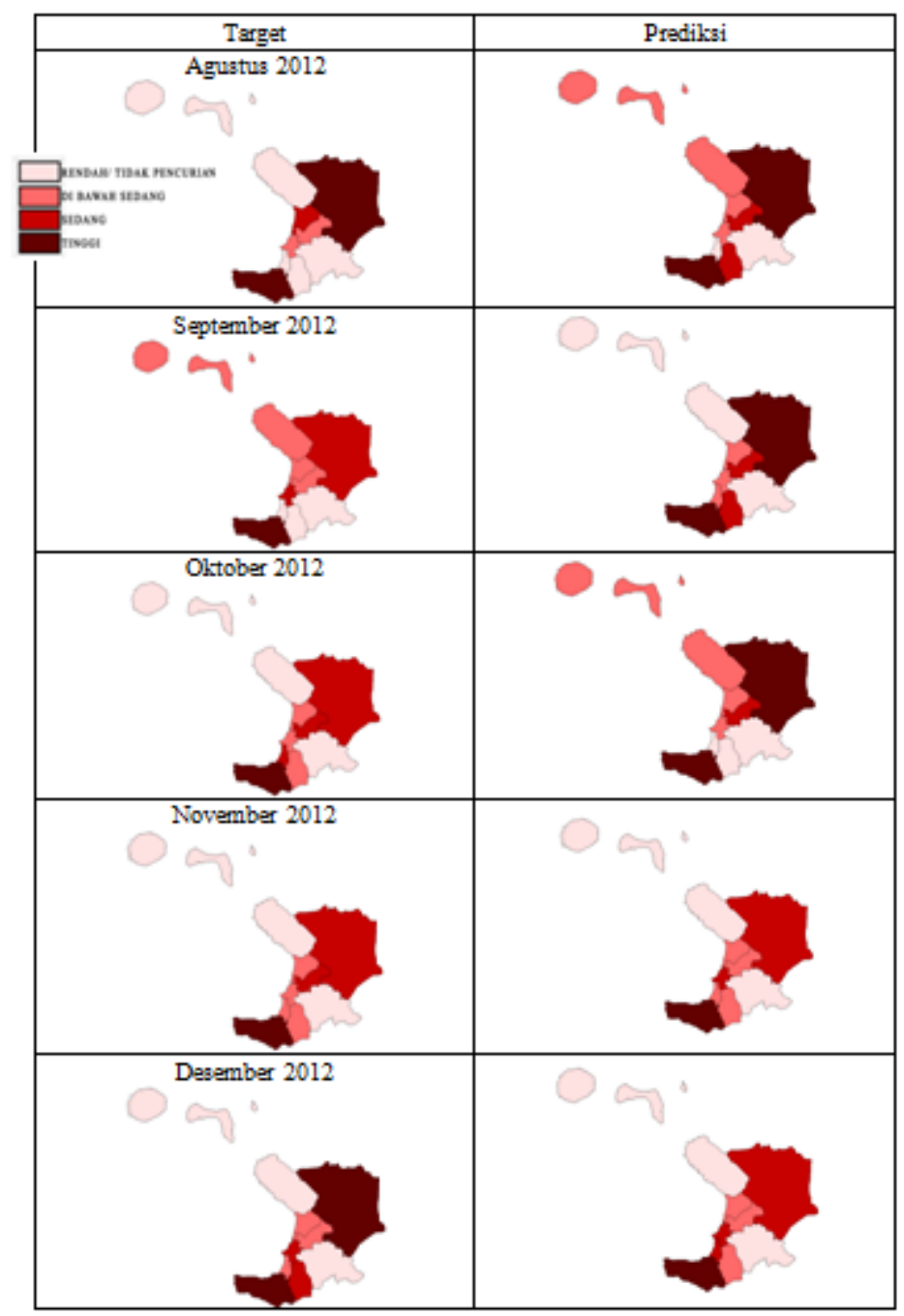

Gambar 2. Pemetaan Target dan Hasil Prediksi 
Pada target Agustus 2012, tingkat kriminalitas tertinggi di kota Manado terkonsentrasi pada kecamatan Malalayang dan kecamatan Mapanget, sedangkan tingkat kriminalitas terendah terkonsentrasi pada kecamatan Tikala, kecamatan Sario, dan kecamatan Wanea. Hasil prediksinya pun menyatakan tingkat kriminalitas tertinggi di kota Manado terkonsentrasi pada kecamatan Malalayang dan kecamatan Mapanget, sedangkan tingkat kriminalitas terendah terkonsentrasi pada kecamatan Tikala dan kecamatan Sario.

Pada target September 2012, tingkat kriminalitas tertinggi di kota Manado terkonsentrasi pada kecamatan Malalayang, dan tingkat kriminalitas terendah terkonsentrasi pada kecamatan Tikala, kecamatan Sario, dan kecamatan Wanea. Hasil prediksinya menyatakan tingkat kriminalitas tertinggi terkonsentrasi pada kecamatan Malalayang dan kecamatan Mapanget, dan tingkat kriminalitas terendah terkonsentrasi pada kecamatan Bunaken dan kecamatan Tikala.

Pada target Oktober 2012, tingkat krimina litas tertinggi di kota Manado terkonsentrasi pada kecamatan Malalayang, dan tingkat kriminalitas terendah terkonsentrasi pada kecamatan Bunaken dan kecamatan Tikala. Sedangkan hasil prediksinya menyatakan tingkat kriminalitas tertinggi terkonsentrasi pada kecamatan Mapanget dan kecamatan Malalayang, dan tingkat kriminalitas terendah terkonsentrasi pada kecamatan Tikala, dan kecamatan Wanea, dan kecamatan Sario.

Target November 2012 dan hasil prediksinya memiliki konsentrasi wilayah yang sama untuk tingkat kriminalitas tertinggi dan tingkat kriminalitas terendah di kota Manado, yaitu tingkat kriminalitas tertinggi terkonsentrasi pada kecamatan Malalayang, dan tingkat kriminalitas terendah terkonsentrasi pada kecamatan Bunaken dan kecamatan Tikala.

Pada target Desember 2012, tingkat kriminalitas tertinggi terkonsentrasi pada kecamatan Malalayang, dan tingkat kriminalitas terendah terkonsentrasi pada kecamatan Bunaken dan kecamatan Tikala. Sedangkan hasil prediksinya menyatakan tingkat kriminalitas tertinggi terkonsentrasi pada kecamatan Malalayang, dan tingkat kriminalitas terendah terkonsentrasi pada kecamatan Tikala dan kecamatan Bunaken.

Dalam penelitian ini, untuk menentukan prediksi tingkat kriminalitas tidak memperhatikan faktor-faktor yang mempengaruhi tingkat kriminalitas tersebut terjadi. Dari hasil prediksi yang diperoleh, epoch dari setiap kecamatan menghasilkan iterasi yang berbeda-beda. Kecamatan Bunaken menghasilkan 74 iterasi, kecamatan Mapanget menghasilkan 43 iterasi, kecamatan Tuminting menghasilkan 34 iterasi, kecamatan Singkil menghasilkan 62 iterasi, kecamatan Wenang menghasilkan 93 iterasi, kecamatan Tikala menghasilkan 20 iterasi, kecamatan Wanea menghasilkan 88 iterasi, kecamatan Sario menghasilkan 72 iterasi, dan kecamatan Malalayang menghasilkan 64 iterasi.

Selanjutnya dilakukan clustering (pengelompokan) tingkat kriminalitas di kota Manado dengan bobot kedekatan (contiguity) yang dipilih adalah Queen's Case. Perhatikan Gambar 3.

Pada target bulan Agustus 2012, kecamatan Bunaken, kecamatan Tuminting, kecamatan Sario, dan kecamatan Wanea memiliki nilai autokore lasi yang negatif dimana nilai pengamatannya rendah tetapi daerah sekitarannya memiliki nilai yang tinggi, keempat kecamatan tersebut ditandai dengan warna bitu muda. Sedangkan untuk hasil prediksinya, kecamatan yang memiliki nilai autokorelasi yang negatif dimana nilai pengamatannya rendah tetapi daerah sekitarannya memiliki nilai yang tinggi ialah kecamatan Tikala dan kecamatan Sario. Pada target bulan September 2012, kecamatan Tuminting dan kecamatan Singkil memiliki nila autokorelasi positif dimana nilai pengamatannya rendah dan daerah sekelilingnya pun rendah, kedua kecamatan tersebut ditandai dengan warna biru tua. Sedangkan kecamatan Sario, kecamatan Wanea, dan kecamatan Malalayang memiliki nilai autokore lasi yang negatif, kecamatan Malalayang memiliki tingkat pengamatan yang tinggi tetapi daerah sekitarannya rendah yang dinyatakan dengan warna merah muda, kecamatan Sario dan kecamatan Wanea memiliki tingkat pengamatan yang rendah tetapi daerah sekitarannya tinggi dinyatakan dengan warna biru muda. Sedangkan untuk hasil prediksinya, kecamatan Sario 
memiliki nilai autokorelasi yang positif dimana tingkat pengamatannya tinggi sedangkan daerah sekitarannya tinggi juga yang dinyatakan dengan warna merah tua, kecamatan Wanea memiliki nilai autokorelasi yang negatif dimana tingkat pengamatannya rendah tetapi daerah sekitarannya tinggi dinyatakan dengan warna biru muda.

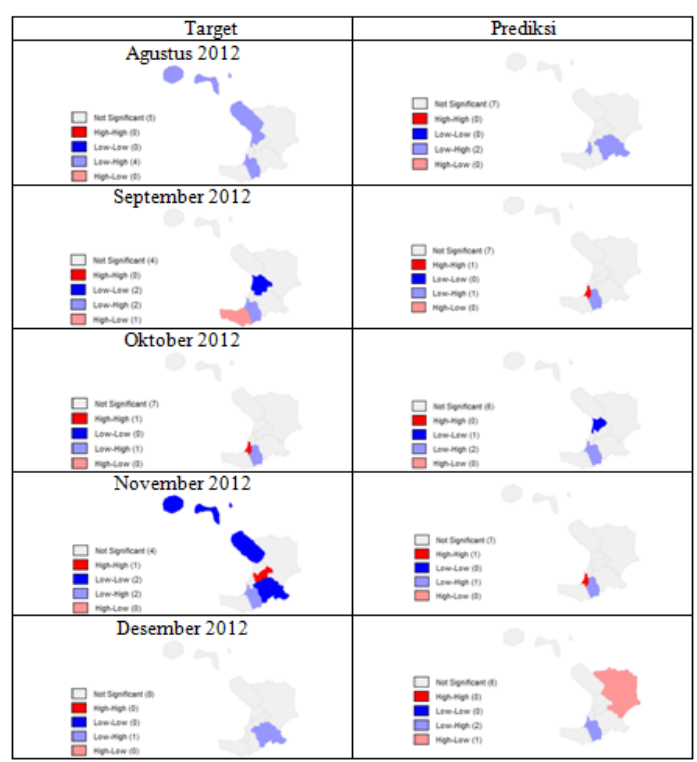

Gambar 3. Clustering Map Target dan Hasil Prediksi

Pada target bulan Oktober 2012, kecamatan Sario memiliki nilai autokore lasi yang positif dimana tingkat pengamatannya tinggi dan daerah sekitarannya juga tinggi yang dinyatakan dengan warna merah tua, kecamatan Wanea memiliki nilai autokorelasi yang negatif dimana tingkat pengamatannya rendah tetapi daerah sekitarannya tinggi dinyatakan dengan warna biru muda. Sedangkan untuk hasil prediksinya, kecamatan Tuminting memiliki nila autokorelasi positif dimana nilai pengamatannya rendah dan daerah sekelilingnya pun rendah, kecamatan tersebut ditandai dengan warna biru tua. Kecamatan Sario dan kecamatan Wanea memiliki nilai autokorelasi negatif dimana tingkat pengamatan rendah tetapi daerah sekitarannya tinggi dinyatakan dengan warna biru muda. Pada target bulan November 2012, kecamatan Bunaken dan kecamatan Tikala memiliki nila autokorelasi positif dimana nilai pengamatannya rendah dan daerah sekelilingnya pun rendah, kedua kecamatan tersebut ditandai dengan warna biru tua. Kecamatan Singkil pun memiliki nilai autokorelasi yang positif tetapi tingkat pengamatannya tinggi dan daerah sekitarannya juga tinggi yang dinyatakan dengan warna merah tua. Kecamatan Sario dan kecamatan Wanea memiliki nilai autokorelasi negatif dimana tingkat pengamatan rendah tetapi daerah sekitarannya tinggi dinyatakan dengan warna biru muda. Sedangkan hasil prediksinya, kecamatan Sario memiliki nilai autokorelasi yang positif dimana tingkat pengamatannya tinggi dan daerah sekitarannya juga tinggi yang dinyatakan dengan warna merah tua, kecamatan Wanea memiliki nilai autokorelasi yang negatif dimana tingkat pengamatannya rendah tetapi daerah sekitarannya tinggi dinyatakan dengan warna biru muda. Pada target bulan Desember 2012, kecamatan Tikala memiliki nilai autokorelasi negatif dimana tingkat pengamatan rendah tetapi daerah sekitarannya tinggi dinyatakan dengan warna biru muda. Sedangkan hasil prediksinya, kecamatan Mapanget memiliki nilai autokorelasi yang negatif dimana tingkat pengamatannya tinggi tetapi daerah sekitarannya rendah yang dinyatakan dengan warna merah muda. Kecamatan Sario dan kecamatan Wanea memiliki nilai autokorelasi negatif dimana tingkat pengamatannya rendah tetapi daerah sekitarannya tinggi dinyatakan dengan warna biru muda. Dari hasil cluster yang telah di peroleh, kecamatan yang dinyatakan dengan warna abu-abu dinyatakan 
tidak signifikan yang berarti pencurian yang terjadi di kecamatan tersebut tidak dipengaruhi oleh kecamatan lain.

\section{Kesimpulan}

Pemetaan kriminalitas memberikan informasi bahwa tingkat pencurian tertinggi di kota Manado selama enam tahun terakhir adalah kecamatan Malalayang, sedangkan tingkat pencurian terendah adalah kecamatan Bunaken. Hasil prediksi tingkat pencurian terlihat dengan je las bahwa prediksi yang diperoleh memiliki nilai yang tidak semuanya sama dengan target, sedangkan hasil dari penge lompokkan wilayah nilai autokorelasi berbeda antara target dan hasil prediksi.

\section{Daftar Pustaka}

[1] Alex H, Kate B. 2001. Mapping and Analysing Crime Data. London: Taylor \& Francis.

[2] Anselin, Luc. 1995. Local Indicators of Spatial Association-(LISA)

[3] Aronoff, Stan. 1995. Geographic Information System: A Management Perspective, WDL Publications, Canada.

[4] Boba, R. 2001. Introduction to Crime Mapping.

[5] Pfeiffer, Dirk et al. (2008). Spatial Analysis in Epidemiologi. Oxford University Press, New York.

[6] Prahasta, Eddy. 2004. Sistem Informasi Geografis: Tutorial Arcview. Informatika Bandung, Bandung

[7] Siang JJ. (2005). Jaringan Syaraf Tiruan dan pemrogramannya menggunakan MATLAB . ANDI, Yogyakarta.

[8] Siang, JJ. 2009. Jaringan Syaraf Tiruan \& Pemrogramannya Menggunakan Matlab, 2nd edition. Penerbit Andi, Yogyakarta. 